\title{
A Contrastive Study on Chinese and English Idioms and the Teaching Methods of Their Translation
}

\author{
You Wang ${ }^{1,2^{*}}$
}

\author{
${ }^{1}$ School of Foreign Languages, Jianghan University \\ ${ }^{2}$ Research Center for Language and Language Education, Central China Normal University \\ *You Wang. Email: wangyou1018@163.com
}

\begin{abstract}
One of the major application of language contrast is translation. Two methods of translation are literal translation and free translation, and two strategies of it are foreignization and domestication. However, the translation of Chinese and English idioms cannot only be focused on the above methods and strategies. The theory of functional equivalence, which is centered on the theory of readers' response, provides a broader perspective for Chinese and English idiom translation and its teaching.
\end{abstract}

Keywords: Chinese and English idioms, literal translation, free translation, foreignization, domestication, functional equivalence, theory of readers' response

\section{INTRODUCTION}

Language contrast and translation are complementary. Linguist Wang Zongyan once pointed out that the beginning of translation is the beginning of language contrast. With the development of linguistics in the 20th century, contrastive linguistics has become an independent discipline. One of the important tasks of contrastive linguistics is to provide theoretical support and practical guidance for translation studies and practice. For example, one of the tasks of contrastive linguistics is to determine the similarities and differences in the same semantic expressions of the languages being compared, and to find out the underlying reasons for this phenomenon. The core of translation is to use various theories and techniques to deal with the similarities and differences between bilingualism and semantic expressions, so as to achieve the best effect. With the help of contrastive linguistics study on the deep causes of this phenomenon, translators can find out the corresponding skills or countermeasures to successfully complete the translation task. Therefore, the essence of translation studies is contrastive studies; and the focus of is to serve translation and better solve the problems encountered in translation [1].

\section{CONTRAST BETWEEN CHINESE AND ENGLISH AND TRANSLATION}

Language is a communicative semiotic system whose function is to express concrete or abstract meanings and concepts. In the process of translating Chinese into English, due to the differences in language communication habits and in the ways of thinking and national customs, the same meaning may have completely different language expressions in Chinese and English. Similarly, the same language expression may not refer to the same semantic meaning. For example, to express the meaning of "speaking of someone, someone is just coming", Chinese uses the idiom "shuo Cao Cao, $\mathrm{Cao} \mathrm{Cao}$ dao", while the corresponding idiom in English is "speak of devil, and devil comes". In Chinese, a person is described as "yi men xin si zhi xiang yi jian shi". In English, there is a idiom "have a one track mind". In Chinese, it is usually a good thing to say that "a person only thinks about one thing with one mind", which means that he is single-minded and not half-hearted. But "have a one track mind" in English is of a critical tone, accusing the person of being narrow-minded and single-minded. Therefore, sometimes we are in a dilemma in our translation work: Should we give up the form equivalence (literal equivalence) which is context free and seek the communicative functional equivalence? Or should we give up the communicative value closely related to the context and seek equivalence in form? In short, it is 
necessary to choose between literal translation and free translation. However, in many cases, the selected translation inevitably has some defects.

Chinese English translation, especially idiom translation, is not only a semantic practice, but also the one related to many fields, involving language communication, language function, national culture, national thinking and so on. Every field here will have an impact on the result and quality of translation. From the perspective of language function, information is the focus of translation. If information is the key point, the purpose of translation is to communicate with the audience and make them respond appropriately. In order to achieve this goal, speech act naturally becomes the focus of translation. The translator should understand the source language text, grasp the semantic, style, occasion and other information of the text, and pass his interpretation of the semantic meaning and other information to the target audience. At this time, the translation of each word and sentence needs to be very accurate.

Translation is not only a practice at the semantic and linguistic functional level, but also an interaction between languages and cultures. For example, the imperial power represented by "dragon" in Chinese is also a symbol of power. But the word "dragon" is a monster in English and a symbol of evil. It can be determined, therefore, that the quality of translation depends not only on the translators' understanding of semantic meaning, style and occasion, but also on the translators' understanding of various cultures of the source language and target language. From the origin of translation we know that the countries or nations needed economic or cultural exchange, and when communication is not available, translation came into being. The emergence of translation makes it possible for one nation to learn from the ideology and culture of another nation, and in turn promotes the development of national economy. Therefore, translation is a collision and exchange of ideology and culture. Culture has regional and national characteristics. Communication between different cultures needs translation as a language carrier. Translation emerges from economic and cultural exchanges, and has an inseparable relationship with ideology and culture. Hence translation is related to language as well as cultural customs.

There is an interactive relationship between language and culture. Culture mainly depends on language, and language is a form of culture. In translation, it is biased to consider only the language itself and not the culture, or to consider only the culture and not its correspondence of the language. Translation is a transformation between two languages, but this transformation is not a simple transformation of symbol system. Professor Liu Miqing believes that the conversion of simple language symbols is only a text description, not a translation [2]. In the process of translation, it is necessary to distinguish the similarities and differences between the two cultures, do multi-dimensional cultural contrastive research, study the semantics, syntax and various expressions of the target language and to predict the response of the target language readers to the translation. Translation is a process of cultural exchange, the completion of which ultimately depends on language itself. Therefore, translation is a process of full integration of language and culture. Both macro language and micro culture are indispensable.

\section{AN OVERVIEW OF TRANSLATION METHODS}

\subsection{Literal translation and free translation}

As mentioned above, we often face such a choice in translation work: whether to use "literal translation" or "free translation". That is, to give up the communicative value closely related to the context and seek formal equivalence; or to give up the formal equivalence (literal equivalence) which is context free to seek communicative functional equivalence. Yan $\mathrm{Fu}$, a translator in the late Qing Dynasty, proposes in the preface of his translation of Theory of Evolution that translation should adhere to the three principles of faithfulness, expressiveness and elegance. Fu Lei, a famous translator of French, believes that "spiritual equivalence is more important than formal equivalence". Eugene Nida, an American translation theorist, puts forward the theory of "dynamic equivalence" and "functional equivalence" in translation. No matter which viewpoint or theory, its foothold is to be faithful to the language and style of the original work, and to fully convey the denotative meaning and associative meaning of the original text. There are two important theories about translation: literal translation and free translation; domestication and foreignization, the former is a translation method, focusing on semantics; the latter is translation strategy, emphasizing culture.

Literal translation and free translation are the oldest and most widely used translation methods. However, there has always been a controversy about their boundaries. Literal translation is centered on the source language, which requires the translation to be completely consistent with the original text in form and meaning. Free translation attaches importance to the target language, makes the original information closer to the target language, and pursues the fluency of the translation. Mr. Xu Yuanchong explains literal translation and free translation as follows: literal translation puts faithfulness to the original texts in the first place, faithfulness to the form in the second place and coherence in the last [3]. In free translation, faithfulness to the content of the original text comes first, but coherence ranks second, not limited to the form of the original text. The author thinks that literal translation and free translation are not opposite. They are related and have no absolute boundary. Xuan Zang, a great master in 
the history of translation in China, translated 75 Buddhist scriptures and 1335 volumes in his whole life. His translation is the peak of Chinese Buddhist scripture translation. Xuan Zang's translation is the reconciliation of literal translation and free translation--"using literal translation more, and free translation as necessary supplement.".

\section{2 domestication and foreignization}

However, both literal translation and free translation are based on semantics. As it is mentioned above, translation is not only related to language, but also to cultural customs. Many idioms cannot be translated with high quality without examining their cultural motivation. Therefore, translation is a process of conveying both the linguistic and cultural information of the source language. Cultural translation involves two methods: Foreignization and domestication. The origin of these terms comes from Schneiermacher's translation thought in 1813, but it was not until 1995 that Venudi proposed these terms.

"Foreignization" is to retain the original components that are "different from the target language". The translation does not conform to the target language convention. This translation method transfers linguistic and cultural information from the source language to the target language without changes, which makes the target language infused with new elements different from its own linguistic norms. "Domestication" refers to the translation, to a great extent, transforming the elements "different from the target language culture" into the familiar elements of the target language. It does not stick to the words and sentences of the original, but always focuses on the pragmatic meaning, and tries to find the same expression from the target language for translation. The translation using this method has little strangeness for the target audience. Compared with domestication, "Foreignization" provides the target language audience with an opportunity to understand the source language and culture, which is more conducive to the communication between the two languages and cultures [4].

From the perspective of the relationship between literal translation, free translation and foreignization, domestication, the focus of literal translation and free translation is on the choice of form and meaning, while the focus of foreignization and domestication is to choose to be closer to the source language or the target language at the cultural level. Literal translation and free translation are translation methods. Foreignization and domestication are translation strategies which are the extension of these two translation methods. The former is a discussion from the perspective of language, but the latter is a cultural consideration. Literal translation and free translation involve no alienation and naturalization. They only involve language, while foreignization and domestication involve language, language style, culture, thinking mode, belief and other fields.

\section{TEACHING STRATEGIES OF CHINESE ENGLISH IDIOMS TRANSLATION}

\subsection{Functional Equivalence Theory}

The translation methods discussed in the previous section----literal translation and free translation, foreignization and domestication----are all theoretical discussions, which do not involve what methods should be used under what circumstances. For example, when we read the English idiom "A blind man who leads against the wall images that it is the boundary of the world", we usually think of using domestication free translation method to translate it into "zuo jin guan tian (sit in the well and watch the sky)", which makes it clear to Chinese readers at a glance. However, although the translation is good, it seems to abandon the cultural connotation of English. It is also easy to cause misunderstanding: Chinese readers might as well think that there are fables like frogs sitting in the well watching the sky in English culture. If the literal translation "A blind man leaning against a wall thinks that the wall is the edge of the world" is adopted, Chinese readers will also be a little confused. Therefore, the asymmetry between the two languages makes it difficult for translators to decide which method is better.

In the late 1960s, Eugene Nida, an American translation theorist, puts forward the theory of functional equivalence, which finds a balance between literal translation and free translation, foreignization and domestication. The core of "functional equivalence theory" is "reader reflection theory", that takes whether the equivalence of the response of the target readers to the target text is equivalent to that of the original readers to the original text as the evaluation criteria of the translation quality. The introduction of readers' response solves the previous debate between literal translation and free translation, because this debate is always a two-point discussion between the source language and the target language (although it involves all aspects of language, it is still language research). Now there cut in a third point, which makes the idea clear. In order to achieve the equivalence between the target readers and the original readers, the translator must strive for the accuracy and fluency of the translation. The specific method of translation depends on which method can make the target readers produce the most similar or even the same reaction as the original readers. To achieve the same response, the main functions of the source language and the translation should be the same. 


\subsection{Vehicle Docking Strategies}

The theory of functional equivalence makes translation closer to the readers in information, culture and function, and provides a new way for translation. With the help of this theory, Chinese English idiom translation will also get better quality translation. However, we repeatedly emphasize that idioms are a special type in language system. Idioms are short and refined but have profound connotation and high frequency of use of metaphorical language. In order to translate metaphors in two different systems, we need to introduce the "vehicle docking strategy", which is proposed by Professor Xujun of Xiamen University (2004:50), to solve the difficulties in the translation of metaphorical words. We think this strategy can also be applied to the translation of Chinese English idioms.

The three elements of metaphor are tenor, vehicle and comparative word. Vehicle is the core of metaphor. No matter what kind of metaphor, the vehicle can not be omitted. The connection between tenor and vehicle depends on association, which is influenced by life experience, understanding of the world, natural environment and many other factors. The natural environment, life experience and world outlook of Chinese and English people are more different than the same, so the metaphors associated with the use of metaphors are naturally more different, thus the information reflected by the same metaphors in the two languages and cultures may also be completely different. Therefore, if we want the readers to have the same reaction to the metaphors in idioms, the effective translation method is to make the metaphors in the source language and the target language connect. Docking is not a simple literal translation or free translation, but to ensure that the two metaphors convey the same image connotation, and to find the relative cultural bearing of the original metaphors in the target language, not just the corresponding word of the original metaphors in the target language.

The core of vehicle docking strategy is connotation docking. First, the translator should fully understand the associative meaning of the vehicle in the original text. The second step is to find the language form with the same associative meaning as the original one in the target language, so as to realize the connection between semantic and rhetorical meaning, thus to achieve "functional equivalence". The tenor of metaphor is the embodiment of cultural image in the language. It may be historical legends, allusions, animals and plants and so on. Cultural images are endowed with national characteristics----cultural images of different nationalities are different. If the cultural images in Chinese are translated into English by literal translation, they are often completely incomprehensible in English. However, if they are expressed in English by using "vehicle docking strategies", the translation will be semantically smooth and functionally equivalent. For example: "There are many butterflies in the stomach.". This idiom can be understood differently in different contexts, so there will be different translations. Let's look at two examples:

Ex. 1. The man she has a crash on is coming to her, she has butterflies in her stomach.

Translation 1：她心仪的男子朝她走来, 她胃里都 是蝴蝶。

Translation 2: 她心仪的男子朝她走来, 她心里很 紧张。

Translation 3: 她心仪的男子朝她走来, 她感觉犹 如小鹿撞心。

Translation 1 is a literal translation. It is impossible for Chinese readers to understand the meaning. Because in English, "butterfly in the stomach" is used to describe nervousness and panic, but in Chinese there is no such figurative meaning. Translation 2 is free translation. Although it basically translates the meaning of the original text, it does not convey the connotation of metaphor and rhetorical effect in the original text. Hence the readers of the original text and the target text will not have the same reaction. Translation 3 is the translation using the strategy of "vehicle docking". It can be inferred from the sentence that her nervousness is caused by the man she loves coming towards her, which indicates that her mood should be not only nervous, but also shy. The Chinese metaphor for women's nervousness and shyness should be "小鹿撞心（deer bumping in the heart）". To use "小鹿撞心" and "butterflies in the stomach" can achieve equivalence in both information and function. So translation 3 is better than translation 1 and 2 .

Ex. 2. I always have butterflies in my stomach before an interview.

Translation 1：面试前我总是胃里都是蝴蝶。

Translation 2: 面试前我总是很紧张。

Translation 3: 面试前我总是心里打鼓。

Similarly, translation 1 is not appropriate, and translation 2 fails to convey metaphorical connotation. In the original sentence, the nervousness before the interview is due to inconfidence or uncertainty, Chinese metaphor of this kind is "心里打鼓（beating the drum in the heart）". Therefore, when "心里打鼓" and "butterflies in the stomach" are used, the information and function are equal.

\subsection{Teaching methods of Chinese and English Idiom Translation}

Idioms have different features from other types of language forms----Idioms are more concentrated, more fixed and concise. The translation of idioms should not 
be stereotype or generalized. We think that from the perspective of functional equivalence theory different methods should be adopted according to different idioms.

Method 1: There are a few idioms with the same meaning in both Chinese and English idioms. Their literal and connotative meaning are both the same or similar. Readers of both sides have the same reaction to these idioms, so literal translation is adopted.

For example, the English idiom "get your beauty sleep" can be translated into Chinese "睡美容觉". The
Chinese idiom "血浓于水" is translated into English as "blood is thicker than water." "出于好心" is translated into English as "out of the goodness of your heart.". But idioms are different from other types of languages. They are refined, rich in connotation and profound in meaning. Literal translation can only translate literal meaning, but can not get the real meaning of idioms. Therefore, the number of idioms that can be completely translated by literal translation is very small.

Table 1. Translation method 1

\begin{tabular}{|l|l|}
\hline \multicolumn{2}{|c|}{ Literal translation of Chinese idioms into English Idioms } \\
\hline 有备无患 & Forewarned is forearmed. \\
\hline 熟能生巧 & Practice makes perfect. \\
\hline 少说多听 & Speak less, listen more. \\
\hline 欲速则不达 & More haste, less speed. \\
\hline 金科玉律 & the golden rule \\
\hline 酸葡萄 & Sour grapes \\
\hline 良药苦口 & A good medicine tastes bitter. \\
\hline 活到老, 学到老 & It's never too old to learn. \\
\hline 袋里有钱, 不如朝中有人 & A friend in court is better than a penny in purse. \\
\hline & Literal translation of English idioms into Chinese Idioms \\
\hline mind your language & 谨慎措辞 \\
\hline rub salt in the wound & 在伤口上撒盐 \\
\hline the golden age & 黄金时代 \\
\hline praise sb. to the skies & (把某人) 捧到天上 \\
\hline hit sb. where it hurts & 刺中 (某人) 痛处 \\
\hline under no circumstances & 绝不 \\
\hline pour cold water on sth. & 泼冷水 \\
\hline A barking dog never bites. & 爱叫的狗不咬人。 \\
\hline
\end{tabular}

Method 2: Chinese idioms have unique images, but they can arouse the same reaction of English readers, and will not lead to misunderstanding. Foreignization literal translation can be used to translate these Chinese idioms into English in order to retain the characteristics of Chinese language and culture. Same principle is adopted when translating English idioms into Chinese.

Table 2. Translation method 2

\begin{tabular}{|l|l|}
\hline \multicolumn{2}{|c|}{ Foreignization literal translation of Chinese idioms into English } \\
\hline 星星之火，可以燎原 & A little spark can start a prairie fire. \\
\hline 千里之行，始于足下 & $\begin{array}{l}\text { A journey of a thousand miles begins with a single } \\
\text { step. }\end{array}$ \\
\hline 倾国倾城 & $\begin{array}{l}\text { her beauty is such as to overthrow cities and ruin } \\
\text { states }\end{array}$ \\
\hline 易如反掌 & as easy as turning over one's hand \\
\hline 玩火自焚 & If you play with fire, you get burned. \\
\hline \multicolumn{2}{|c|}{ Foreignization literal translation of English idioms into Chinese } \\
\hline
\end{tabular}




\begin{tabular}{|l|l|}
\hline A cat may look at the king. & 猫也有权见国王。 \\
\hline A flow of words is no proof of wisdom. & 口若悬河不代表有才智。 \\
\hline ivory tower & 象牙塔 \\
\hline the ins and outs (of sth.) & 事情的里里外外 \\
\hline Business is the salt of life. & 事业是人生之盐。 \\
\hline Beauty is a good letter of introduction. & 美貌是一封有力的推荐信。 \\
\hline the early bird catches the worm. & 早起的鸟有虫吃。 \\
\hline A bird in hand is worth two in the bush. & 一鸟在手好过双鸟在林。 \\
\hline be on the side of the angels & 站在天使（或正义）的一边 \\
\hline one by one & 一个接一个 \\
\hline hit sb. where it hurts & 刺中（某人）痛处 \\
\hline
\end{tabular}

Method 3: The image or figurative meanings in some Chinese idioms are not found in English, and there is no idiom with the same function in English. The same reaction cannot be caused in English readers.
Domestication free translation method is used to translate Chinese idioms into English, and vice versa. Most idioms are translated by this method.

Table 3. Translation method 3

\begin{tabular}{|c|c|}
\hline \multicolumn{2}{|c|}{ Domestication Free translation of Chinese idioms into English } \\
\hline 三只手 & a pickpocket \\
\hline 不到黄河不死心 & $\begin{array}{l}\text { refuse to give up until all hope is } \\
\text { gone }\end{array}$ \\
\hline 火中取栗 & gain profit in risk \\
\hline 借花献佛 & to offer presents provided by someone else \\
\hline 胸有成竹 & to have some plans ready to meet any situation \\
\hline 虚张声势 & to put on a false show of strength \\
\hline 轩然大波 & a big dispute \\
\hline 咬文嚼字 & to be over-fastidious about the choice of words \\
\hline 白璧无瑕 & without a spot on one's reputation \\
\hline 敉帚千金 & to treasure one's own things which are worthless \\
\hline \multicolumn{2}{|c|}{ Domestication free translation of English idioms into Chinese } \\
\hline Every dog has its day. & 人人皆有得意日。 \\
\hline fall from grace & 失去人心 \\
\hline When your ship comes in. & 待到成功时 \\
\hline One's meat is another's poison. & 萝卜白菜各有所爱。 \\
\hline easy meat & 容易完成的事 \\
\hline take it with a grain of salt & 对......表示怀疑 \\
\hline There is truth in wine. & 酒后吐真言 \\
\hline the eleventh hour & 最后关头 \\
\hline an elder statesman & 元老 \\
\hline hit and miss & 随意地 \\
\hline the acid test (of sth.) & 决定性的考验 \\
\hline
\end{tabular}




\begin{tabular}{|l|l|}
\hline apple of Sodom & 华而不实之物 \\
\hline put sth. down to experience & 从......中吸取教训 \\
\hline one in the eye for sb./sth. & 挫折, 失败 \\
\hline face the music & 承担自己言行的后果 \\
\hline make eyes at sb. & 向......抛媚眼 \\
\hline with your eyes open & 头脑清醒 \\
\hline
\end{tabular}

Method 4: Chinese idioms with historical allusions should be translated literally by foreignization. The cultural tradition of the original text should be retained, but notes must be added to make English readers understand and have the same reaction. Vice versa.

Table 4. Translation method 4

\begin{tabular}{|l|l|}
\hline \multicolumn{2}{|c|}{ Foreignization literal Translation of Chinese idioms into English (with notes) } \\
\hline 打落水狗 & $\begin{array}{l}\text { to beat a drowning dog. (to crush a defeated } \\
\text { enemy completely) }\end{array}$ \\
\hline 三顾茅庐 & $\begin{array}{l}\text { to make three calls at the thatched cottage (to } \\
\text { resquest sb. repeatedly to take up a responsible } \\
\text { post) }\end{array}$ \\
\hline 三个臭皮匠, 合成一个诸葛亮 & $\begin{array}{l}\text { Three cobblers with their wits combined equal } \\
\text { Zhuge Liang. (Two heads are better than one.) }\end{array}$ \\
\hline \multicolumn{1}{|c|}{ Foreignization literal Translation of English idioms into Chinese (with notes) } \\
\hline be a law onto oneself & 自己就是自己的法律 (乾坤独断) \\
\hline before the flood & 大洪水前（远古时代） \\
\hline An Achilles' heel & 阿克琉斯的脚后跟（致命的弱点） \\
\hline A good dog deserves a good bone. & 好狗值得给个好骨头（有劳必赏） \\
\hline an act of God & 上帝的行为（天灾） \\
\hline Pandora's Box & 潘多拉的盒子 (不幸的礼物, 灾难） \\
\hline corn in Egypt & 埃及的玉米（大量的谷物） \\
\hline
\end{tabular}

Method 5: Although images in some Chinese idioms do not exist in English, there are idioms in English which have similar meanings and functions to the Chinese idioms. We can use metaphor docking strategy and domestication free translation. Vice versa.

For example, Chinese idioms "爱屋及乌": "house" and "crow" can not cause any association for English readers, for the crow is not a "bird that can bring bad luck" in English. Literal translation, in function, can not have the same effect in Chinese, nor can it produce the same reaction in the heart of English readers. But in English, there is an idiom "love me, love my dog" which has the same pragmatic function as "爱屋及乌". We can choose this idiom as the translation of "爱屋及乌".

Table 5. Translation method 5

\begin{tabular}{|l|l|}
\hline \multicolumn{2}{|c|}{ Domestication free translation of Chinese idioms into English } \\
\hline 县花一现 & a flash in the pan \\
\hline 爱屋及乌 & Love me, love my dog. \\
\hline 一贫如洗 & as poor as a church mouse \\
\hline 家常便饭 & bread and cheese \\
\hline 沽名钓誉 & fish for compliments \\
\hline 言传身教 & A good example is the best sermon. \\
\hline 瑞雪兆丰年 & A good winter brings a good summer. \\
\hline 倾盆大雨 & It's raining cats and dogs. \\
\hline 祸从口出 & A man may dig his grave with his teeth. \\
\hline
\end{tabular}




\begin{tabular}{|l|l|}
\hline 笑里藏刀 & A man may smile and smile and be villain. \\
\hline 对牛弹琴 & Cast pearls before swine \\
\hline 狼来了 & cry wolf \\
\hline 远亲不如近邻 & $\begin{array}{l}\text { A near friend is better than a far-dwelling } \\
\text { kinsman. }\end{array}$ \\
\hline 千里之堤, 溃于蚁穴 & A little leak will sink a great ship. \\
\hline 一朝被蛇咬, 十年怕井绳。 & A burnt child dreads the fire. \\
\hline 一不做, 二不休 & in for a penny, in for a pound \\
\hline 以牙还牙, 以眼还眼 & an eye for an eye, a tooth for a tooth \\
\hline
\end{tabular}

\section{CONCLUSION}

One of the main service objects of language contrast is translation, which has two methods: literal translation and free translation; two strategies: foreignization and domestication. The former focuses on language itself, making a choice between form and meaning; the latter focuses on culture. Chinese English idiom translation can not only focus on the discussion of whether to use literal or free translation, domestication or foreignization, because this discussion does not take the readers' response into account. The theory of functional equivalence with the readers' response theory as its core provides a broader approach to idiom translation. Under the framework of functional equivalence, this essay divides Chinese and English idioms into five categories and discusses their translation methods and strategies.

\section{REFERENCES}

[1] Wang You, A Multi-dimensional Contrastive Study on Chinese and English Idioms, in: Doctoral Dissertation, Central China Normal University, May 2015.

[2] Liu Miqing, An outline of Cultural Translation, Wuhan: Hubei Education Press, 1999.

[3] $\mathrm{Xu}$ Yuanchong, Literal Translation and Free Translation I, in: Foreign Languages, No. 6, 1980.

[4] Peng Qinghua, A study of English idioms from a pragmatic Perspective, Beijing: social Science Literature Press, 2007. 